west England, which are used to transmit electricity at 132 kilovolts throughout that part of the country. The work which he carried out for Kennedy and Donkin was of great value to them and was much sppreciated on account of his sound judgment and his facility in finding the best method of attacking any complex problem.

In 1935 Boys was appointed secretary of the Institution of Naval Architects. He filled this post with great success and was popular with the members and staff and trusted by successive presidents of the Institution-the late Viscount Stonehaven and Admiral of the Fleet Lord Chatfield. Boys was also a good linguist; and when the Institution was invited to Germany in 1939, he attended as one of its representatives. He quickly became convinced of Germany's warlike intentions and on his return volunteered his services to the Admiralty. His offer was accepted, and in September 1939 he moved to Bath and became professional secretary to the Director of Naval Construction, retaining general control over Institution affairs. Although he was not a naval architect by training, he was soon 'giving useful help to the directors under whom he servedSir Stanley Goodall and Mr. C. S. Lillicrap. Ill-health forced him to retire from the Admiralty in 1944. During his fatal illness he wrote or dictated letters to the office and his friends so long as he was able and showed great courage and patience throughout.

Boys had a good personality, mixing well with those he met, and was a man of knowledge and ability in many directions. He leaves a widow and a young son.

L. WOOLLARD.

\section{Mr. F. Percy Smith}

F. Percy Smrth, one of the pioneers of British film production, died on March 24.

It was in 1908 that Smith threw up an appointment with the Board of Education and gave himself up entirely to cinematography. He started working for Charles Urban and specialized in Nature and microscopic work. Even in these early days he had developed his special technique of speeded-up cinematography and had shown, in "The World before your Eyes" series, the beauties of the flower unfolding on the screen. Smith worked for Charles Urban for several years; but had no real opportunity of showing what he could do until in 1921 he joined Bruce Woolfe and took his part in the production of the "Secrets of Nature" series which, largely through Smith's contribution, has gone on ever since and has thus created a record for this or any other country of continuous production over a period of twenty-five years.

British cinematography has suffered a great loss as Smith's work was known and admired in nearly every country where cinematograph films are shown. Whenever a representative selection of British films has been shown to special audiences, something emanating from Smith's studio has always been included. In 1930 at the gala presentation organized by the Federation of British Industries to the delegates to the Imperial Conference his "Plants of the Underworld" was shown, and later, in 1933 at a similar gala presentation to world press representatives, he contributed "Gathering Moss".

Although much of Smith's work was shown in the theatres, and many will remember the weird beauty of his "Plants of the Underworld" and the drama of "The Life of a Plant", yet his main work was rather in the scientific film. Here he was undoubtedly in a class by himself, especially in the field of biology. In collaboration with Dr. Julian Huxley, he contributed a series of biological subjects that have done more to bring about the use of the cinema film in schools than any other single event. In connexion with this, Dr. Julian Huxley remarks: "Percy Smith had extraordinary patience and pertinacity in getting the results he wanted. In addition he was extremely ingenious in devising apparatus and gadgets of every description, His work was essential for the building up of high technical standards in the difficult art of biological film-making."

Although his studies of the chick and the frog were of very high quality, there is little doubt that it was his botanical films made in collaboration with Dr. E. J. Salisbury that opened up fresh possibilities to the cinematograph camera. As Dr. Salisbury writes : "Mr. Percy Smith was a first-rate cinematographer, who combined great technical skill with patience and observational acumen. The film which he took of the growth of roots is not only one of his most successful efforts, but exemplifies these qualities in a high degree. The knowledge of what is the lifehistory of a plant or its normal behaviour under particular conditions is not the end, but only the starting point in their pictorial portrayal. It was in the patience necessary to ascertain the precise phase of a phenomenon that best lent itself to pictorial record that Percy Smith exhibited so high a degree of skill almost amounting to genius."

The study, research and the patience that were necessary to complete such subjects as the lifehistories of the fern and the moss were enormous, and nobody except a person whose sole interest lay in his work would have undertaken them. The fern film took three years to complete and that on the moss two and a half.

In the field of international competition, Smith's work had upheld the prestige of Great Britain, and prizes had been awarded his films in open competition against all comers, notably at Brussels and Venice.

Smith's was a strange personality. He had no thought for anything other than his work, and the only assistant he would tolerate was his wife. He was of a retiring and shy disposition, but with a keen sense of humour and a positive genius for the invention of 'gadgets'. In his studio he had machines to record the growth of plants; these, of course, had to work night and day. They were controlled by clockwork, made by himself, and it was essential they continued to function continuously, sometimes, for several weeks. As even he must sleep sometimes, he devised a means whereby if any of the machines stopped for any reason, it rang a bell by his bedside and woke him up.

In Percy Smith the British film industry loses a lovable personality and one whose work has done more than a little to uphold the prestige of British films. The sympathy of all will go out to his wife, who assisted him so ably, in her great loss.

We regret to announce the following deaths:

Miss Emilia F. Miram, of the Zoological Museum of the Academy of Sciences of the U.S.S.R.

Prof. Andreas P. Semenov-Tian-Shansky, honorary president of the Russian Entomological Society.

Prof. William Trelease, emeritus professor of botany in the University of Illinois, on January 1, aged eighty-seven. 